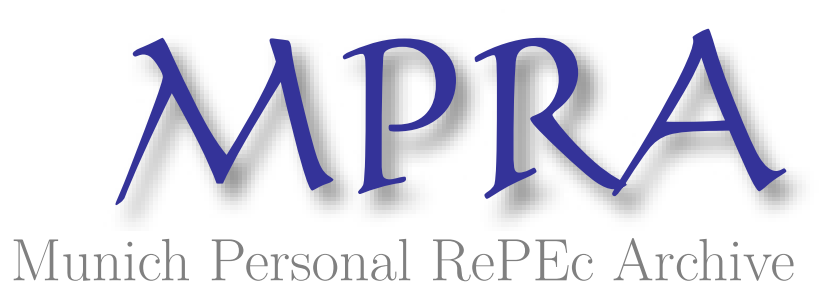

\title{
Supplier selection criteria and methods: past, present and future
}

\author{
MUKHERJEE, KRISHNENDU
}

Heritage Institute of Technology

January 2014

Online at https://mpra.ub.uni-muenchen.de/60079/

MPRA Paper No. 60079, posted 26 Nov 2014 06:08 UTC 


\title{
Supplier selection criteria and methods: past, present and future
}

\author{
Krishnendu Mukherjee* \\ Department of Mechanical Engineering, \\ Heritage Institute of Technology, \\ Kolkata-700107, India \\ E-mail: gopal.mech2010@gmail.com \\ *Corresponding author
}

\begin{abstract}
Sole purpose of supplier selection is not limited to get supply at low cost and at right time. Supplier selection is a strategic decision to fulfil company's goal for long period of time at low risk. To accomplish this objective companies are moving from reactive buying to proactive buying to give more priority to co-creation of wealth with supplier/s. Considering this issue an attempt has been made in this paper to give systematic review of supplier selection and evaluation process from 2005 to 2012 to answer three main questions: (i) Which method is more appropriate for supplier selection? (ii) Which evaluating criteria were most cited? (iii) Is present trend of research is adequate enough to support proactive buying? In this regard, 78 papers are classified into 10 categories to identify factors affecting supplier selection and evaluation process. Statistical analysis has been conducted with software "R" to have better insight on the trend of research. Recommendations and future work is also included to verify inadequacy of existing methods, if any, to support proactive buying process.
\end{abstract}

Keywords: Proactive supplier selection; Decision support system; Multi-criteria decision making tools; Statistical analysis; Review.

Biographical notes: Krishnendu Mukherjee received his first class Bachelor of Engineering degree in Mechanical Engineering in 1998 from Jadavpur University and a Masters degree in Mechanical Engineering in 2002 from Birla Institute of Science and Technology, Pilani, India. He is pursuing his $\mathrm{PhD}$ from Jadavpur University, Kolkata, India. He has eleven years teaching experience in India and abroad. He also worked as a reviewer of EJOR, Elsevier and Journal of Operational Research Society, UK, PalGrave Macmillan publication. Currently, he is an Assistant Professor with the Department of Mechanical Engineering, Heritage Institute of Technology, West Bengal, India. He has published papers in Computers and Industrial Engineering, International Journal of Applied Engineering Research, IEEE, International Journal of Business Intelligence and Systems Engineering, International Journal of Computational Systems Engineering etc. His main research areas include supplier selection, green supply chain, decision engineering and mass 
customisation. His biography is also selected by Marquis Who's Who in 2014. He is the member of DSI,USA; ISM,USA; EUROMA; EURO SC Group etc.

\section{Introduction}

"The objectives of the purchasing function are that it should obtain the right materials (meeting quality requirements), in the right quantity, for delivery at the right time and right place from the right source (a supplier who is reliable and will meet its commitments in a timely fashion), with the right service (both before sale and after sale), and at the right price." (Gaither, 1996 as cited in Moynihan et al. 2006).

Jabil Circuit Inc. one of the largest companies in the Tampa Bay area survived from the disruption of supply chain due to 2011 Tōhoku earthquake and Tsunami in Japan for its effective strategy and the cooperation of its suppliers. In 2012, Japanese car makers faced supply shockwave due to severe flood at the low-lying areas of Ayutthaya and Pathumthani provinces of Thailand where vast majority of suppliers are located. Success of Jabil Circuit Inc. proves that behind every great success of any company there was an even bigger supplier and logistician. Any disruption in upstream supply may cause tremendous disaster in entire supply chain and compel organization to take risk. Risks in supply chain are broadly classified as internal risk that appears in normal operation and external risk that come from outside the supply. Selection of right supplier/s could minimize external risks. Supplier selection could be either single sourcing where only one supplier is selected to fulfil the entire demand or multiple sourcing where a group of suppliers are selected to fulfil the need of entire demand. Risk in supply chain could be minimized by internal integration and external integration of supply chain entities. External integration strongly encourages single sourcing by establishing long-term relationship between supplier and organization. Today companies are more interested about proactive buying instead of reactive buying. Reactive buying gives highest priority to cost and restrict sharing of knowledge and information. Proactive buying considers procurement as main management function. In proactive buying, suppliers are not only selected on lowest cost basis rather on various strategic issues to fulfil long term goal of any company. Proactive procurement prefers multiple sourcing to have better negotiation options and encourages sharing of knowledge and information i.e. co-creation of wealth. In this regard a comparative analysis of single and multiple sourcing is conducted initially to show various advantages of both processes, shown in table 1. 
Table 1 Single sourcing versus multiple sourcing.

\begin{tabular}{|l|l|}
\hline \multicolumn{1}{|c|}{ Single sourcing } & \multicolumn{1}{|c|}{ Multiple sourcing } \\
\hline $\begin{array}{l}\text { Concept of this strategy comes from just } \\
\text { in-time (JIT) philosophy. Uncertainty in } \\
\text { supply is very high as buyer deals with } \\
\text { single supplier. }\end{array}$ & $\begin{array}{l}\text { Multiple sourcing is preferable if reliability } \\
\text { of one supplier is very poor. It reduces } \\
\text { safety stock without increasing stock out } \\
\text { problem (Kelle and silver, 1990).It reduces } \\
\text { uncertainty in supply but increases the } \\
\text { fixed cost associated with operating } \\
\text { multiple suppliers (Agrawal and } \\
\text { Nahmias, 1997) }\end{array}$ \\
\hline $\begin{array}{l}\text { No competition exists as only one supplier } \\
\text { is involved. It gives quantity discount from } \\
\text { order consolidation, reduce order lead time } \\
\text { and logistical lead time (Hahn et } \begin{array}{l}\text { Reduction of price is achieved through } \\
\text { al.,1986;Bozarth et al.,1998) }\end{array}\end{array}$ & $\begin{array}{l}\text { greater assurance of timely delivery and } \\
\text { greater upside volume } \\
\text { (Ramasesh et al., 1991). }\end{array}$ \\
\hline $\begin{array}{l}\text { It is applicable where goodwill trust exists } \\
\text { between buyer and supplier. }\end{array}$ & $\begin{array}{l}\text { In presence of low ordering cost and } \\
\text { highly variable lead-times dual sourcing is } \\
\text { better than single sourcing (Ramasesh et } \\
\text { al., 1991). }\end{array}$ \\
\hline Low threat to loss of information. & $\begin{array}{l}\text { Since business data is shared among } \\
\text { various suppliers, proper security measures } \\
\text { should be taken. }\end{array}$ \\
\hline
\end{tabular}

Literature review shows rich collection of work on supplier selection. Researchers used various methods such as analytic hierarchy process (AHP), multi objective programming (MOP), data envelopment analysis (DEA), mixed integer programming (MIP), goal programming (GP), genetic algorithm (GA), analytic network process (ANP), case based reasoning (CBR), data mining (DM), cluster analysis (CA), activity based costing (ABC),technique for order preference by similarity to ideal solution(TOPSIS), rough sets theory (RST), quality function deployment (QFD), neural network (NN), multi attribute utility theory (MAUT). Some researchers combined at least two of the above technique for supplier selection. For instance, AHP-GP, AHP-LP, DEA-AHP, DEA-MOP etc. In this regard, table 2 shows various techniques for single sourcing and multiple sourcing supplier selection.

Table 2 Various techniques for single sourcing and multi sourcing supplier selection

\begin{tabular}{|l|l|l|l|l|}
\hline \multicolumn{3}{|c|}{ Single sourcing } & \multicolumn{2}{c|}{ Multi sourcing } \\
\hline Sl. & Methods & Remark & Sl. & Methods \\
No. & & & No. & \\
\hline 1. & Linear & Depends heavily on & 1. & Mixed integer programming. \\
\hline
\end{tabular}




\begin{tabular}{|c|c|c|c|c|}
\hline & $\begin{array}{l}\text { weighted } \\
\text { point }\end{array}$ & human judgments. & & \\
\hline 2. & $\begin{array}{l}\text { Categorical } \\
\text { method }\end{array}$ & $\begin{array}{l}\text { Depends heavily on } \\
\text { human judgments. }\end{array}$ & 2. & Goal programming. \\
\hline 3. & Cost ratio & $\begin{array}{l}\text { Very complicated and } \\
\text { need more financial } \\
\text { information. }\end{array}$ & 3. & $\begin{array}{l}\text { Single/ multi } \\
\text { programming. }\end{array}$ \\
\hline 4. & AHP & $\begin{array}{l}\text { More accurate than any } \\
\text { other method } \\
\text { (Ghodsypour } \\
\text { O'Brien,1998) }\end{array}$ & 4. & $\begin{array}{l}\text { Multi attribute utility theory and } \\
\text { AHP; AHP-LP; AHP-GA; AHP } \\
\text { and multi-objective possibilistic } \\
\text { linear programming (AHP- } \\
\text { MOPLP) etc. }\end{array}$ \\
\hline
\end{tabular}

This paper is organized as follows: section 2 covers extensive literature review with detail statistical analysis, section 3 gives recommendations to improve existing supplier selection methods and section 4 concludes the paper.

\section{Literature review and statistical analysis}

Research work related to supplier selection is considerably very high. For instance, from www.sciencedirect.com alone 13,201 articles were found with the search word "supplier selection" for publication 2009 onwards. In this regard, about 78 papers are selected from peer review journals from 2005 to 2012. Papers are selected based on the reputation of journal and citation of papers. Some papers from other journals are also considered because of their rich content. Related articles on supplier selection are grouped and broadly classified into 10 categories, shown in table 3 .

Table 3 Classification of research work

\begin{tabular}{|c|c|c|}
\hline SI.No. & Classification of research work & Author/s \\
\hline 1 & $\begin{array}{l}\text { Supplier selection for single item or multiple } \\
\text { items under stochastic demand and/ supply }\end{array}$ & Guan et al.; Bilsel and Ravindran ; \\
\hline 2 & Supplier selection for manufacturing industry & van der Rhee et al.; Ustun and Demirtas; \\
\hline 3 & Supplier selection for electronics industry & $\begin{array}{l}\text { Yu and Tsai; Amin and Razmi; Lee et } \\
\text { al.; Önüt et al. }\end{array}$ \\
\hline 4 & $\begin{array}{l}\text { Supplier selection under price break with or } \\
\text { without volume discount }\end{array}$ & $\begin{array}{l}\text { Amid et al.; Xia and Wu; Kokangul and } \\
\text { Susuz; Che and Wang }\end{array}$ \\
\hline 5 & $\begin{array}{l}\text { Decision support system (DSS) for supplier } \\
\text { selection }\end{array}$ & Cakir and Canbolat \\
\hline 6 & Supplier selection for green supply chain & Hsu andHu; Shaw et al.; Tate et al.; \\
\hline
\end{tabular}




\begin{tabular}{|lll|}
\hline 7 & $\begin{array}{l}\text { Supplier selection for new product } \\
\text { development }\end{array}$ & Kim and Wagner \\
8 & Supplier selection for customized system & Sawik, T. \\
9 & Supplier selection by various techniques & Faez et al.; Li et al.; Chan and Kumar; \\
& & Wu,M.; Lin, R.-H.; Wang et al.; Hong \\
& & and Ha; Levary, R.R. \\
10 & Strategic supplier selection & Huang and Keskar; Wang et al. \\
\hline
\end{tabular}

Review shows that majority of the work is related to the development of various methods for supplier selection. In this paper, literature survey is conducted to find the followings:

1. To identify most cited criteria for supplier selection.

2. To identify different methods for supplier selection.

3. To identify the trend of supplier selection methods.

4. To check the adequacy of present trend for proactive buying.

5. To identify all journals where research work related to supplier selection is published frequently.

6. To identify countries, based on frequency of publication as the most promising place for supplier selection researchers.

Study shows that supplier selection methods can be broadly categorized into two category-single model and integrated model, shown in fig 1. 


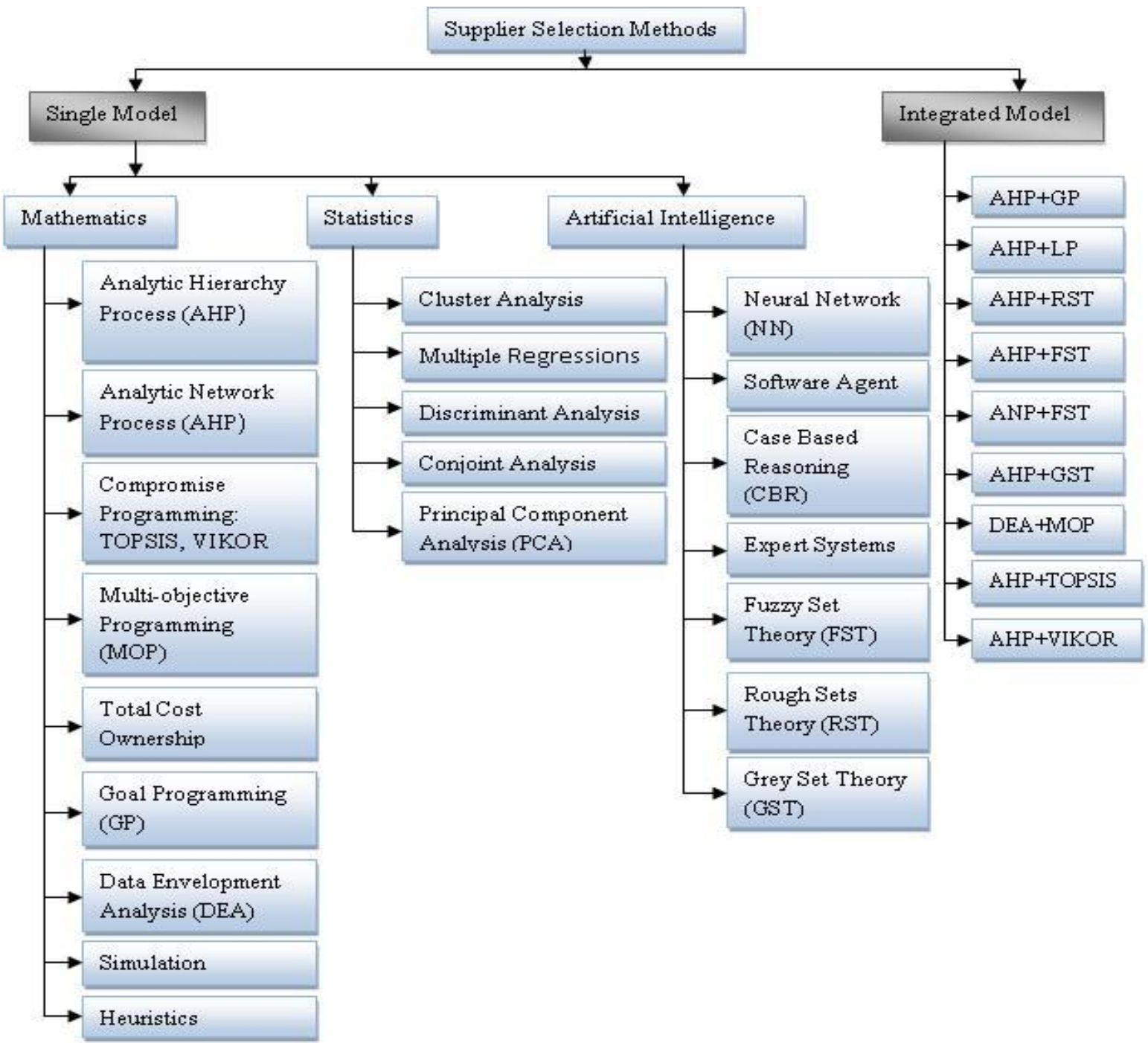

Fig. 1 Classification supplier selection methods (Source: Mukherjee et al.)

Among all methods- analytic hierarchy process (AHP), analytic network process (ANP) and their integrated model is mostly used by various researchers, shown in fig.2. AHP and the integrated method of AHP is most cited method for supplier selection. Moreover, this study reveals that present research trend on supplier selection gives more emphasizes on multiple suppliers selection instead of single supplier selection, shown in fig.3.As shown in Fig.1, mathematical, statistical or artificial intelligence 
(AI) could be used for single sourcing as well multiple sourcing. Integrated models usually combined with linear program (LP), genetic algorithm (GA) or particle swarm optimization (PSO) to allocate order among multiple suppliers. Among several criteria-cost, quality, delivery and service are mostly cited by various researchers, shown in table 4 . However, different researchers used same criterion with different terminology, ex. delivery time, on-time delivery, delivery reliability etc. Table 5 shows different methods proposed by various researchers for electronics industry, automobile industry, manufacturing industry, textile industry etc.

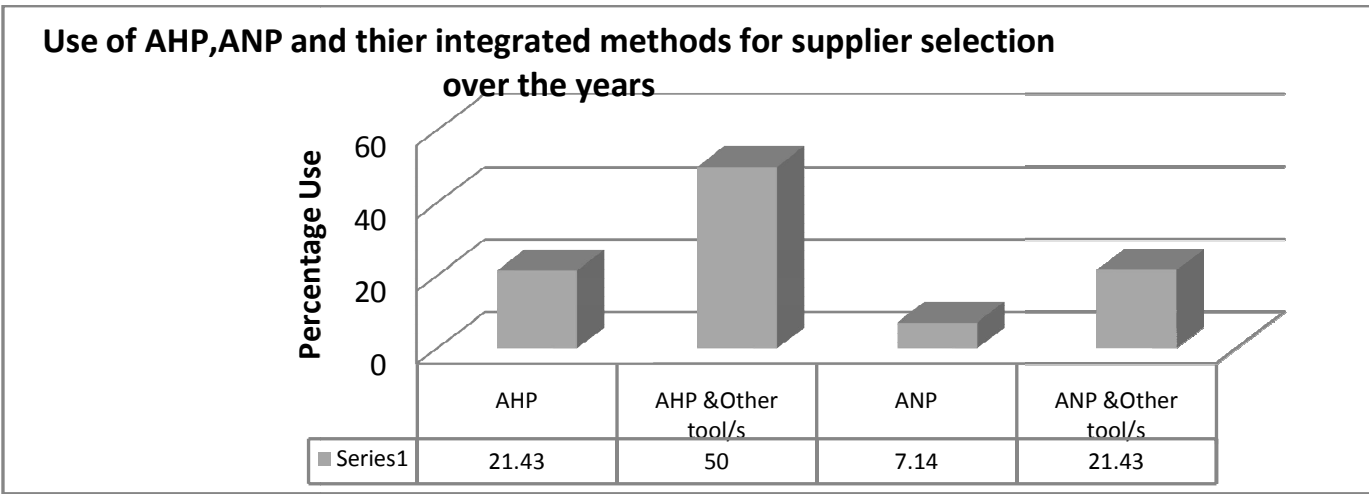

Fig.2 Use of AHP, ANP and their integrated approach (Source: Mukherjee et al.)

Distribution of review papers for single and multiple sourcing over the

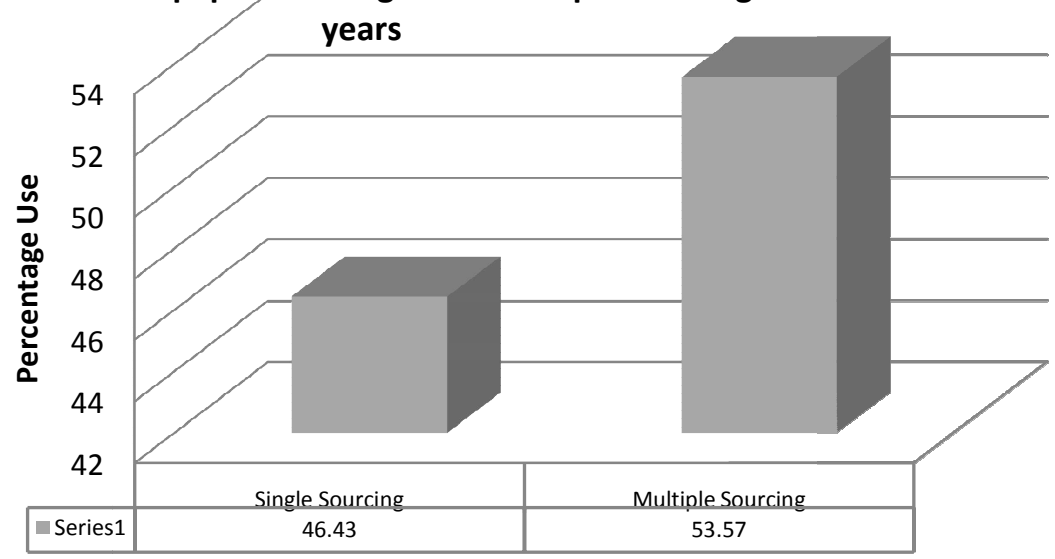

Fig.3 Distribution of review papers for single and multiple sourcing (Source: Mukherjee et al.) 
Table 4 Supplier selection criteria

\begin{tabular}{|c|c|c|c|c|c|c|c|c|c|c|c|c|c|c|c|c|c|c|c|c|c|c|c|}
\hline Year & Author/s & î & 莺 & $\begin{array}{l}\stackrel{\vec{D}}{D} \\
\stackrel{\vec{D}}{0} \\
0\end{array}$ & 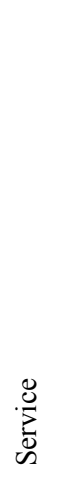 & 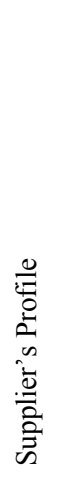 & 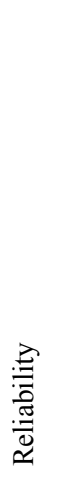 & 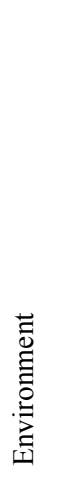 & 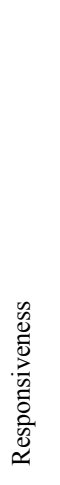 & 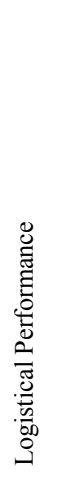 & 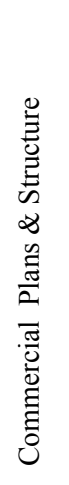 & 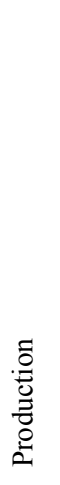 & 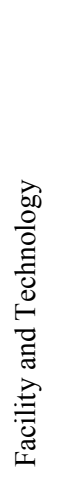 & 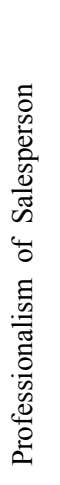 & 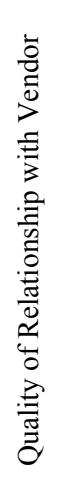 & 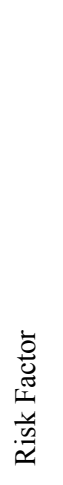 & 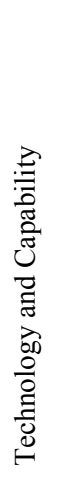 & 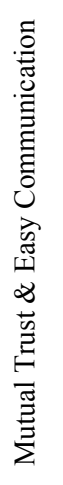 & 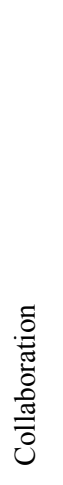 & 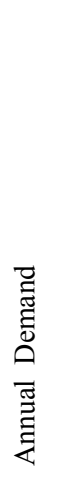 & 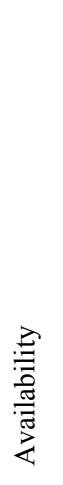 & 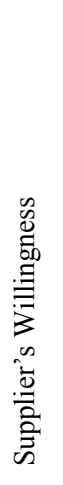 & 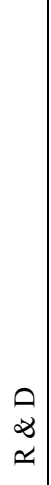 \\
\hline 2005 & $\begin{array}{l}\text { Ozden Bayazit and Birsen } \\
\text { Karpak }\end{array}$ & & & & & & & & & $\mathrm{x}$ & $\mathrm{x}$ & $\mathrm{x}$ & & & & & & & & & & & \\
\hline 2006 & $\begin{array}{l}\text { Huan-Jyh Shyur and Hsu-Shih } \\
\text { Shih }\end{array}$ & $\mathrm{x}$ & $\mathrm{x}$ & $\mathrm{x}$ & & & & & $\mathrm{x}$ & & & & $\mathrm{x}$ & $\mathrm{x}$ & $\mathrm{x}$ & & & & & & & & \\
\hline 2007 & FU Yao and LIU Hongli & $\mathrm{x}$ & $\mathrm{x}$ & $\mathrm{x}$ & & $\mathrm{x}$ & & & & & & & & & & & & & & & & & \\
\hline 2007 & $\begin{array}{l}\text { Felix T.S. Chan and Niraj } \\
\text { Kumar }\end{array}$ & $\mathrm{x}$ & $\mathrm{x}$ & & $\mathrm{x}$ & $\mathrm{x}$ & & & & & & & & & & $\mathrm{x}$ & & & & & & & \\
\hline 2007 & Weijun Xia and ZhimingWu & $\mathrm{x}$ & $\mathrm{x}$ & & $\mathrm{x}$ & & & & & & & & & & & & & & & & & & \\
\hline 2007 & Min Wu & $\mathrm{x}$ & $\mathrm{x}$ & $\mathrm{x}$ & $\mathrm{x}$ & $\mathrm{x}$ & & & & & & & & & & & $\mathrm{x}$ & & & & & & \\
\hline 2007 & $\begin{array}{l}\text { Sanjay Jharkharia and Ravi } \\
\text { Shankar }\end{array}$ & $\mathrm{x}$ & $\mathrm{x}$ & & & $\mathrm{x}$ & & & & & & & & & & & $\mathrm{x}$ & & & & & & \\
\hline 2007 & $\begin{array}{l}\text { Cevriye Gencer and Didem } \\
\text { Gürpinar }\end{array}$ & & $\mathrm{x}$ & & & $\mathrm{x}$ & & & & & & & & & & & $\mathrm{x}$ & & & & & & \\
\hline 2007 & $\begin{array}{l}\text { Ezgi Aktar Demirtas and } \\
\text { Ozden Ustun }\end{array}$ & $\mathrm{x}$ & $\mathrm{x}$ & $\mathrm{x}$ & $\mathrm{x}$ & $\mathrm{x}$ & & & & & & & & & & & $\mathrm{x}$ & $\mathrm{x}$ & & & & & \\
\hline 2008 & $\begin{array}{l}\text { Ali Kokangul and Zeynep } \\
\text { Susuz }\end{array}$ & $\mathrm{x}$ & & $\mathrm{x}$ & & & & & & & & & & & & & $\mathrm{x}$ & & $\mathrm{x}$ & & & & \\
\hline 2008 & Wang et al. & $\mathrm{x}$ & $\mathrm{x}$ & & $\mathrm{x}$ & & & & & & & & & & & & & & & & & & \\
\hline 2008 & Reuven R. Levary & & & & & & $\mathrm{x}$ & & & & & & & & & $\mathrm{x}$ & & & & & & & \\
\hline 2008 & $\begin{array}{l}\text { Jing-Rung Yu and Chao-Chia } \\
\text { Tsai }\end{array}$ & $\mathrm{x}$ & $\mathrm{x}$ & $\mathrm{x}$ & $\mathrm{x}$ & & & $\mathrm{x}$ & & & & & & & & & & & & & & & \\
\hline 2008 & $\begin{array}{l}\text { Ozan Cakir and Mustafa S. } \\
\text { Canbolat }\end{array}$ & $\mathrm{x}$ & $\mathrm{x}$ & & & & & & & & & & & & & & & & & $\mathrm{x}$ & $\mathrm{x}$ & & \\
\hline 2008 & $\begin{array}{l}\text { Sung Ho Ha and Ramayya } \\
\text { Krishnan }\end{array}$ & & & & & & & & & & $\mathrm{x}$ & & & & & & $\mathrm{x}$ & $\mathrm{x}$ & & & & & \\
\hline 2008 & Amy H.I. Lee & $\mathrm{x}$ & $\mathrm{x}$ & $\mathrm{x}$ & & & & & & & & & & & & $\mathrm{x}$ & & & & & & & \\
\hline 2008 & $\begin{array}{l}\text { Eleonora Bottani and Antonio } \\
\text { Rizzi }\end{array}$ & & & & & & & & & & & & & & & & $\mathrm{x}$ & $\mathrm{x}$ & & & & $\mathrm{x}$ & \\
\hline 2008 & Rong-Ho Lin & $\mathrm{x}$ & $\mathrm{x}$ & $\mathrm{x}$ & & & & & & & & & & & & & $\mathrm{x}$ & & & & & & \\
\hline 2008 & $\begin{array}{l}\text { Semih Önüt, Selin Soner Kara, } \\
\text { and Elif Is_ik }\end{array}$ & $\mathrm{x}$ & $\mathrm{x}$ & $\mathrm{x}$ & & & & & & & & & & & & & & & & & & & \\
\hline 2008 & $\begin{array}{l}\text { Ozden Ustun and Ezgi Aktar } \\
\text { Dem irtas }\end{array}$ & $\mathrm{x}$ & $\mathrm{x}$ & $\mathrm{x}$ & $\mathrm{x}$ & $\mathrm{x}$ & & & & & & & & & & & $\mathrm{x}$ & $\mathrm{x}$ & & & & & \\
\hline 2008 & Wann-Yih Wu et al. & $\mathrm{x}$ & $\mathrm{x}$ & & & & & & & & & & & & & & & & & & & & \\
\hline 2009 & Chia-Wei Hsu and Allen H. Hu & & $\mathrm{x}$ & & & & & & & & $\mathrm{x}$ & & & & & & & & & & & & $\mathrm{x}$ \\
\hline
\end{tabular}


Supplier selection criteria and methods: past, present and future

Table 5 Review of supplier selection methods from 2005 to 2012

\begin{tabular}{|c|c|c|}
\hline $\begin{array}{ll}\text { Method } & \text { Mathematics }\end{array}$ & Year & Author/s \\
\hline AHP & 2005 & Bayazit and Karpak \\
\hline AHP & 2007 & Yao and Hongli \\
\hline AHP & 2008 & Reuven R. Levary \\
\hline AHP & 2012 & Bruno et al. \\
\hline AHP & 2012 & Parthiban et al. \\
\hline ANP & 2007 & Gencer and Gürpinar \\
\hline ANP & 2009 & Hsu and $\mathrm{Hu}$ \\
\hline GA & 2008 & Che and Wang \\
\hline PSO & 2006 & Mouli et al. \\
\hline $\begin{array}{l}\text { Multi-objective chance constrained } \\
\text { programming }\end{array}$ & 2011 & Bilsel and Ravindran \\
\hline Stochastic mixed-integer programming & 2011 & Tadeusz Sawik \\
\hline Integer linear programming & 2012 & Choudhary and Shankar \\
\hline \multicolumn{3}{|l|}{ Statistics } \\
\hline & 2012 & Riedl et al. \\
\hline Multiple Analysis of Variance & & \\
\hline Discrete choice analysis (DCA) & 2008 & Van der Rhee, B., et al. \\
\hline Descriptive Statistics, ANOVA etc & 2012 & Jin Wang \\
\hline \multicolumn{3}{|l|}{ Artificial Intelligence } \\
\hline Vague set & 2008 & Zhang et al \\
\hline 2-tuple linguistic computing & 2010 & Wen-Pai Wang \\
\hline \multicolumn{3}{|l|}{ Integrated Model } \\
\hline F-AHP and GA & 2006 & Kubat and Yuce \\
\hline AHP,QFD and PGP & 2006 & Sarfaraz and Balu \\
\hline Fuzzy AHP TOPSIS & 2006 & Chen et al. \\
\hline AHP and proportional rule & 2007 & Che et al. \\
\hline $\begin{array}{l}\text { CBR, AHP, Fuzzy Set and mixed integer } \\
\text { programming }\end{array}$ & 2007 & Fayez et al. \\
\hline Fuzzy extended AHP & 2007 & Chan and Kumar \\
\hline $\begin{array}{l}\text { AHP, rough set and multi-objective mixed } \\
\text { integer programming }\end{array}$ & 2007 & $\mathrm{Xia}$ and $\mathrm{Wu}$ \\
\hline TOPSIS-AHP simulation & 2007 & Min Wu \\
\hline $\begin{array}{l}\text { AHP and multi-objective non-linear } \\
\text { integer programming }\end{array}$ & 2008 & Kokangul and Susuz \\
\hline $\mathrm{AHP}$ and integer programming & 2008 & $\mathrm{Yu}$ and Tsai \\
\hline AHP,DEA or NN & 2008 & Ha and Krishnan \\
\hline $\begin{array}{l}\text { FAHP and fuzzy multiple goal } \\
\text { programming }\end{array}$ & 2008 & Lee et al. \\
\hline $\begin{array}{l}\text { FAHP and fuzzy multiple goal } \\
\text { programming }\end{array}$ & 2008 & Amy H.I. Lee \\
\hline Cluster analysis, fuzzy logic and AHP & 2008 & Bottani and Rizzi \\
\hline $\begin{array}{l}\text { Fuzzy set, interpretive structural } \\
\text { modeling(ISM) and AHP }\end{array}$ & 2008 & Yang et al. \\
\hline FAHP and fuzzy multiple goal & 2009 & Amy H.I. Lee \\
\hline
\end{tabular}




\begin{tabular}{|c|c|c|}
\hline \multicolumn{3}{|l|}{ programming } \\
\hline AHP and Goal programming & 2012 & Erdem and Göçen \\
\hline F-AHP and Fuzzy Linear programming & 2012 & Shaw et al. \\
\hline NGT ,ANP and TOPSIS & 2006 & Shyura and Shih \\
\hline ANP and Archimedean Goal & & \\
\hline Programming (AGP) & 2007 & Demirtas and Ustun \\
\hline FANP-MOLP & 2008 & Rong-Ho Lin \\
\hline Delphi and ANP & 2008 & Wu et al. \\
\hline Fuzzy ANP and fuzzy TOPSIS & 2008 & Önüt et al. \\
\hline ANP and multi-objective mixed integer & & \\
\hline LP & 2008 & Ustun and Dem irtas \\
\hline Delphi , ANP and MIP & 2009 & Wu et al. \\
\hline $\begin{array}{l}\text { Data mining and mixed integer } \\
\text { programming. }\end{array}$ & 2005 & Hong et al. \\
\hline $\begin{array}{l}\text { Supplier capability and price analysis } \\
\text { chart is prepared based on price index and }\end{array}$ & & \\
\hline $\begin{array}{l}\text { supplier process performance. } \\
\text { Imprecise data envelopment analysis }\end{array}$ & 2005 & Chen et al. \\
\hline (IDEA) & 2007 & Reza Farzipoor Saen \\
\hline Fuzzy C-means algorithm and PSO & 2007 & Mehdizadeh and Moghaddam \\
\hline Fuzzy rough set and GA & 2007 & Guo et al. \\
\hline $\begin{array}{l}\text { Various configurable matrices for supplier } \\
\text { selection is discussed }\end{array}$ & 2007 & Huang and Keskar \\
\hline $\begin{array}{l}\text { Fuzzy weighted average and multi- } \\
\text { objective mixed integer LP }\end{array}$ & 2007 & Amid et al. \\
\hline $\begin{array}{l}\text { Grey theory and multi-attribute decision } \\
\text { making. }\end{array}$ & 2007 & Li et al. \\
\hline $\begin{array}{l}\text { Multi-objective mixed integer stochastic } \\
\text { programming }\end{array}$ & 2007 & Guan et al. \\
\hline $\begin{array}{l}\text { Fuzzy NN, GA and principal component } \\
\text { analysis (PCA) }\end{array}$ & 2008 & Moghadam et al. \\
\hline Fuzzy hierarchical TOPSIS & 2008 & Wang et al. \\
\hline Machine learning \& MCDM & 2008 & Hong and $\mathrm{Ha}$ \\
\hline $\begin{array}{l}\text { Fuzzy TOPSIS and mixed integer } \\
\text { programming }\end{array}$ & 2008 & Lin and Chang \\
\hline Weighted LP & 2008 & Wan Lung Ng \\
\hline Fuzzy set theory and QFD & 2008 & Amin and Razmi \\
\hline Fuzzy SMART & 2008 & Chou and Chang \\
\hline Simulation of CCP,MOP,DEA & 2008 & $\mathrm{Wu}$ and Olson \\
\hline $\begin{array}{l}\text { Fuzzy linguistic quantifier with order } \\
\text { weighted aggregation }\end{array}$ & 2009 & Wang et al. \\
\hline $\begin{array}{l}\text { Possibility fuzzy multi-objective } \\
\text { programming }\end{array}$ & 2010 & Wu et al. \\
\hline Fuzzy set theory and VIKOR & 2010 & Sanayei et al. \\
\hline Bi-objective mixed integer programming & 2010 & Tadeusz Sawik \\
\hline $\begin{array}{l}\text { A weighted max-min multi-objective } \\
\text { model }\end{array}$ & 2011 & Amid et al. \\
\hline $\begin{array}{l}\text { Fuzzy TOPSIS and 2-stage stochastic } \\
\text { programming }\end{array}$ & 2011 & Selin Soner Kara \\
\hline Fuzzy set and Grey theory & 2012 & Mukherjee and Kar \\
\hline
\end{tabular}


Supplier selection criteria and methods: past, present and future

Table 6 Statistical analysis of distribution of research papers from 2005 to 2012

\begin{tabular}{|llllll|}
\hline $\begin{array}{l}\text { Data Analysis } \\
\text { Mathematics }\end{array}$ & Statistics & $\begin{array}{l}\text { Artificial } \\
\text { Intelligence }\end{array}$ & $\begin{array}{l}\text { Integrated } \\
\text { Method }\end{array}$ & Skewness & Kurtosis \\
12 & 3 & 2 & 50 & 1.025 & 2.217 \\
$\begin{array}{l}\text { Integrated } \\
\text { Method }\end{array}$ & & & & & \\
$\begin{array}{l}\text { Integrated } \\
\text { AHP } \\
18\end{array}$ & $\begin{array}{l}\text { Integrated } \\
\text { ANP }\end{array}$ & Others & Skewness & Kurtosis & \\
\hline
\end{tabular}

Statistical analysis has been conducted with software " $R$ " to find trend of research. As shown in table 6, among four different methods researchers are keen to use integrated method as skewness is positive, i.e. 1.025. Among different integrated methods researchers are more interested about the use of integrated AHP as skewness is negative, i.e. -0.2641. Obtained kurtosis value in both cases is less than 3 . Therefore both distributions follows platykurtic curve which is less peaked than normal curve. Simplicity and effectiveness of AHP could be the expected reason for its extensive use.

Supplier selection process is product specific and industry specific. Review shows that more attention is paid to electronics industry, shown in fig. 6. Short product life cycle, advanced manufacturing process, complexity of design and manufacturing process could be the possible reason to demand more effective and robust supplier selection for electronics industry. However, very limited no of articles are found related to supplier selection for mass customized system. Although companies like Dell, BMW, Nike etc are extensively using the concept of mass customization such as assembly-to-order (ATO), build-to-order (BTO), engineer-to-order (ETO) etc. Strategies of mass customization demand proactive supplier selection instead of reactive supplier selection. Present trend of research is adequate and applicable for proactive buying with little modification. For instance, among all criteria for supplier selection more priority should be given to supplier's willingness, mutual trust of buyer and seller, technical capability of suppliers etc. Proactive buying demands multiple sourcing and considers sourcing as strategic sourcing. Present trend also gives more emphasizes on multiple suppliers selection. Thus present methods can be used by considering all strategic issues of procurement so that every procurement could add value to business. More research works are highly expected to develop effective supplier selection methods for such complex and advanced manufacturing system. 


\section{1\% Country wise distribution of research}

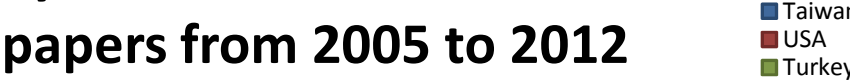

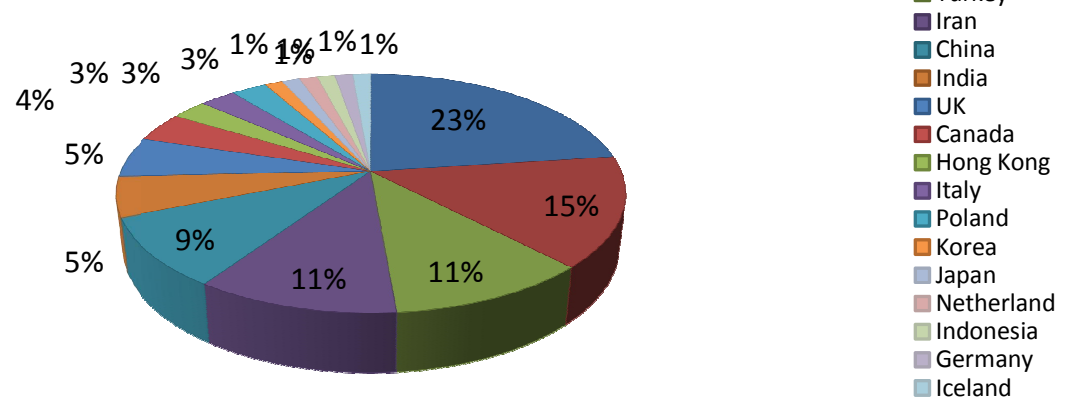

Fig. 4 Country wise distribution of review papers from 2005 to 2012

As shown in fig. 4, major contribution in research related to supplier selection is obtained from Taiwan, USA, Turkey, Iran and China. There cumulative work related is about 69 percent of total research work. In this regard, India and UK both occupies same position. 57 percent of total research work related to supplier selection comes from Expert Systems with Application (ESWA), International Journal of Production Economics (IJPE) and Computers and Industrial Engineering (CIE). Contribution of other journals is also significant, shown in fig.5.

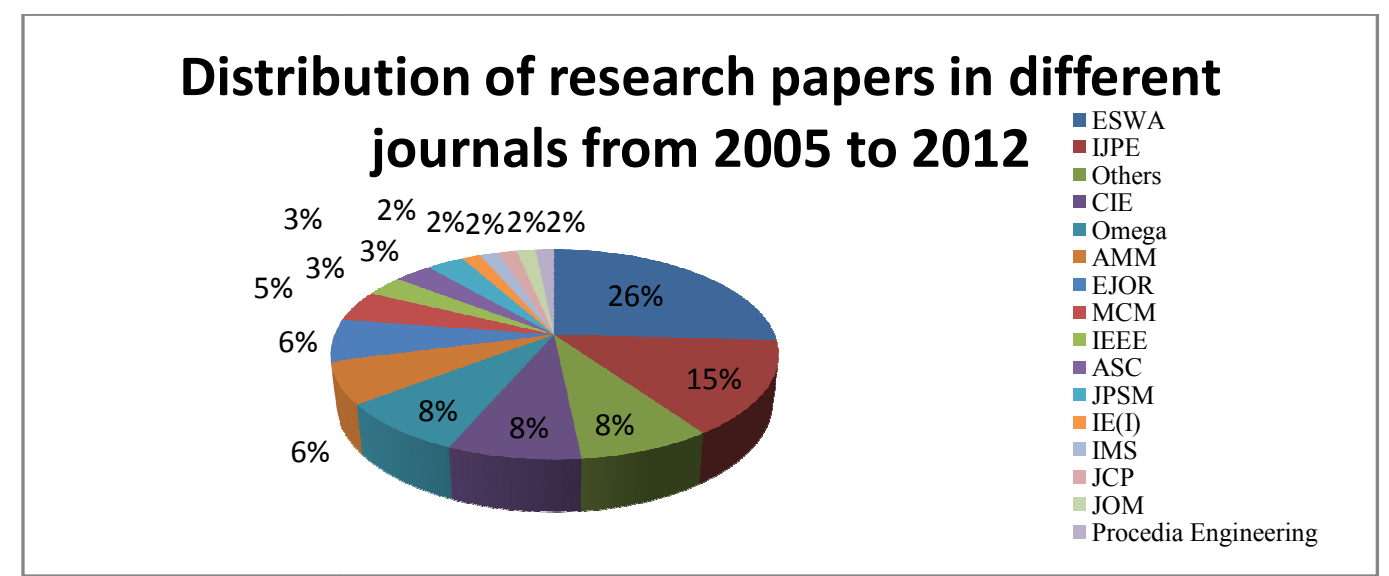

Fig. 5 Distribution of research papers in different journals from 2005 to 2012 


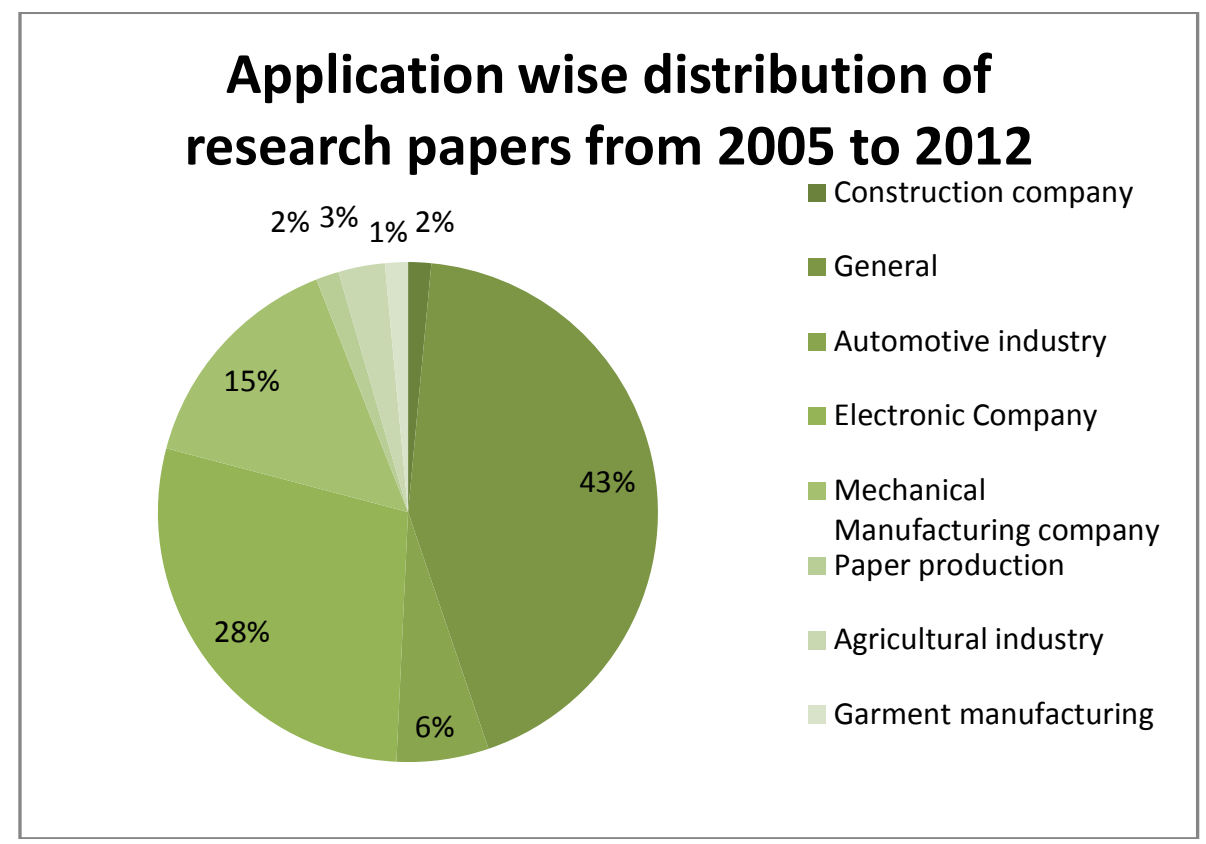

Fig.6 Application wise distribution of research papers from 2005 to 2012.

\section{Major observations and recommendations}

Majority of research papers used multi-criteria decision analysis (MCDA) tools for supplier selection process to trade off palpable and non-palpable criteria. Therefore, it is pertinent to verify the usability of MCDA tools for supplier selection. Classical MCDA tools are not suitable to deal uncertainties. Fuzzy version of MCDA tools is used for long in this regard. But fuzzy version can't deal all type of uncertainties. It is quite suitable for imprecision and vagueness. Moreover, selection of appropriate fuzzy number is highly subjective and contextual. A more defined framework is quite expected in this regard to select best membership for fuzzification of classical MCDA tools. Very recently two methods got attention to deal uncertainty - Cloud and D-number. Either of them can be used with MCDA tools to deal uncertainties of supplier selection.

Time complexity and rank reversal problem are the main limitations of classical MCDA tools. Rank of existing alternatives may change due to the introduction of new alternative. Rank reversal problem can be avoided by appropriate selection of normalization method. Fuzzification of MCDA tools can't guaranty to generate better solution. Rather it can spoil 
existing algorithm by increasing computational time. Unfortunately, very limited researchers justified the use of MCDA tools for specific supplier selection problem in their paper.

Finally, decision of any decision maker is always subjective. Same decision maker can give different decision to same problem under different situation. To achieve consensus group decision making, brain storming etc are highly advisable. Naturalistic decision making process can also be used with MCDA tools to improve decision making process. Naturalistic decision making (NDM) is commonly used for very complex situation and it is not used much for supplier selection. Interested readers can refer relevant papers in this regard.

\subsection{Factors affecting proactive supplier selection process}

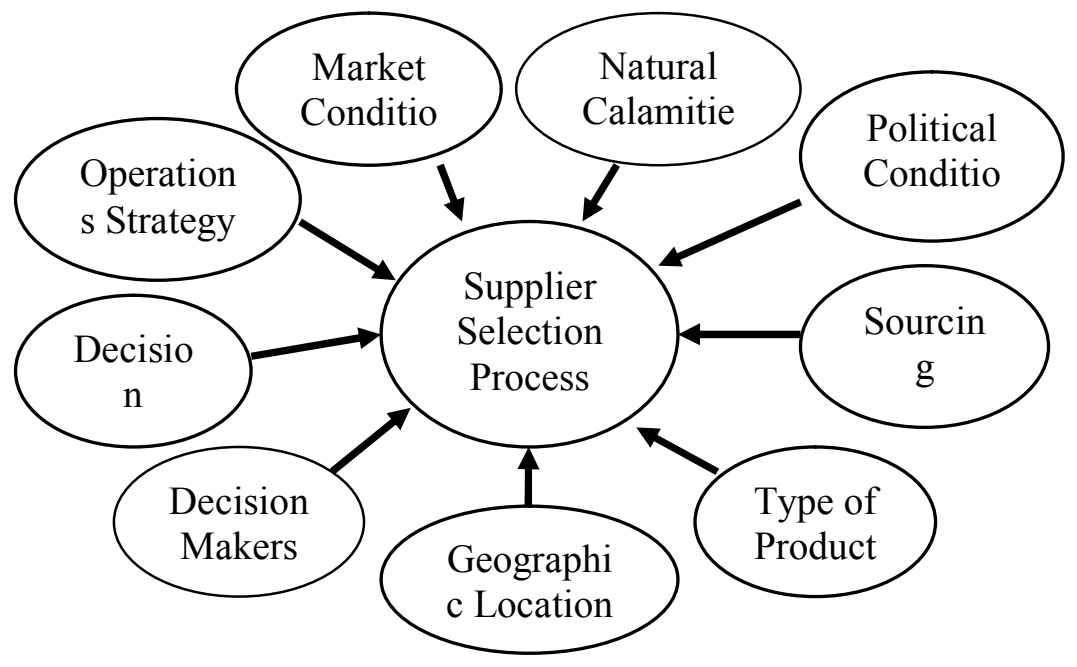

Fig. 7 Factors affecting proactive supplier selection process

Supplier selection process is always influenced by demand side and supply side uncertainties. Volatile market condition brings demand uncertainties and compels decision makers to go for stochastic supplier selection process instead of deterministic supplier selection process. Still such uncertainties are controllable. Uncertainties brought by natural calamities are often uncontrollable in nature, ex., supply shockwave created for Japanese carmakers due to severe flood in Thailand. Like natural disasters, political conditions can cause supply chain disruption and thereby affect 
supplier selection process. Type of product, complexity of design and availability of material usually brings supply side uncertainties. All such uncertainties are expected to be prevented, if not completely, by operations and sourcing strategy. Such strategies are geographic location specific. For instance, IKEA, the largest furniture manufacturer, fails to maintain market share in China as they used same strategy for US and China. Finally, supplier selection process is highly influenced by decision maker's choice and selection criteria. It is expected that if all factors shown in fig. 7 are controlled effectively then every procurement will add value to business.

\subsection{Modification of order allocation model}

Literature review shows that supplier selection and order allocation is a two stage problem. In first stage, suppliers are evaluated and selected from supply base by MCDA tools w.r.t some predefined criteria. In the second stage, orders are allocated to selected suppliers by a mathematical model. Single sourcing does not require the second stage as total demand is fulfilled by one supplier. Order allocation stage is important for proactive supplier selection. Order allocation is basically an optimization problem and can be broadly classified as single objective optimization and multiple objective optimizations. Single objective optimization gives equal priority to all constraints. Therefore, it is better to use multiple objective optimization instead of single objective optimization. Usually, objective functions for order allocation are linear weighted functions. Such as total cost of purchase (TCP), total value of purchase (TVP) etc. Usually, TCP is minimized and TVP is maximized with respect to some constraints quality, late delivery etc (Ghodsypour and O'Brien,2001; Ustun and Demirtas, 2008). The most important constraints for any supplier selection problems are supplier capacity, minimum order quantity to fulfill demand, and cost or budgetary limitations (M.Kumar et al.,2004; Ghodsypour and O'Brien,1998). TVP can maximize value but can't guaranty reliability of purchase to reduce the impact of supply chain disruption. Therefore, total valuable of purchase (TVP) should be modified as total value of reliable purchase (TVRP) to consider reliability of each selected suppliers during order allocation (Mukherjee et al.,2013). It should be one of the central criteria for proactive buying as proactive buying avoids defective supplies. Finally, in majority of order allocation problem price or cost of each product is considered as constant. It may not be the case of real life problem. Cost could be the function of quantity. Hence, it is better to use 
non-linear weighted order allocation problem instead of linear weighted order allocation problem.

\section{Conclusions}

Proactive supplier selection is a multi-criteria decision based optimization problem. It is a strategic process as judicious selection of supplier brings seed of success to company. To survive in heterogeneous volatile market an effective supplier selection method is highly required for any company. In this paper, it was found that present trend of supplier selection is integrated or hybrid approach of two or more methods. Second, it was observed that AHP and their integrated methods are most preferred among researchers. Third, it was shown that multiple sourcing is much preferred than single sourcing. Fourth, it was observed that cost, quality, delivery and service are the most cited criteria for supplier selection. It was also observed that different researchers used different name for same or almost same criteria. Hence, taxonomy is required to name various criteria for supplier selection. Fifth, present trend is adequate for proactive buying. However, little modification is required for supplier selection criteria to give more priority to supplier's willingness, mutual trust of buyer and seller etc. Finally, it was mentioned that total value of purchase (TVP) should be replaced by total value of reliable purchase (TVRP) to reduce inbound supply chain risk. In this regard several factors are identified and recommendations are mentioned to aid practitioners and decision makers to solve supplier selection problem effectively.

\section{Acknowledgements}

Author expresses gratitude to two anonymous reviewers for their constructive comments which helped to improve this paper.

\section{References}

Amid, A., Ghodsypour, S.H. and O’Brien, C. (2011), “A weighted max-min model for fuzzy multi-objective supplier selection in a supply chain", International Journal of Production Economics, Vol.131, pp.139-145.

Amin, S. H. and Razmi, J.(2008), “An integrated fuzzy model for supplier management: A case study of ISP selection and evaluation", Expert Systems with Applications, doi:10.1016/j.eswa.2008.10.012. 
Amid, A., Ghodsypour, S.H. and O’Brien, C. (2007), “A weighted additive fuzzy multiobjective model for the supplier selection problem under price breaks in a supply Chain”, International Journal of Production Economics, doi:10.1016/j.ijpe.2007.02.040.

Agrawal, N and Nahmias, S (1997), "Rationalization of the supplier base in the presence of yield uncertainty", Production and Operations Management, Vol. 6, No.3,pp. 291308.

Bruno, G., Esposito, E., Genovese, A. and Passaro, R.(2012), “AHP-based approaches for supplier evaluation: Problems and perspectives", Journal of Purchasing \& Supply Management,Vol.18,pp.159-172.

Bilsel, R. U. and Ravindran, A. (2011), "A multiobjective chance constrained programming model for supplier selection under uncertainty", Transportation Research Part B, Vol. 45, pp. 1284-1300.

Bottani, E. and Rizzi, A. (2008), "An adapted multi-criteria approach to suppliers and products selection-An application oriented to lead-time reduction", International Journal of Production Economics, Vol. 111,pp.763-781.

Bayazita, O. and Karpak, B., "AN AHP APPLICATION IN VENDOR SELECTION", In: Proc ISAHP 2005, Honolulu, Hawaii, July 8-10, 2005.

Bozarth, C, Handfield, R, Das, A (1998), "Stages of global sourcing strategy evolution An exploratory study”, Journal of Operations Management, Vol. 16, No.2-3,pp.241-255.

Choudhary, D. and Shankar, R.(2012), "Joint decision of procurement lot-size, supplier selection, and carrier selection", Journal of Purchasing \& Supply Management, http://dx.doi.org/10.1016/j.pursup.2012.08.002.

Cakir, O., and Canbolat, M. S. (2008), “A web-based decision support system for multicriteria inventory classification using fuzzy AHP methodology", Expert Systems with Applications, Vol. 35, pp. 1367-1378.

Che, Z.H. and Wang, H.S. (2008), "Supplier selection and supply quantity allocation of common and non-common parts with multiple criteria under multiple products", Computers \& Industrial Engineering, Vol. 55, pp. 110-133.

Chou, S.-Y. and Chang, Y.-H.(2008), “A decision support system for supplier selection based on a strategy-aligned fuzzy SMART approach", Expert Systems with Applications, Vol. 34, pp. 2241-2253.

Chan, F. T.S. and Kumar, N. (2007), "Global supplier development considering risk factors using fuzzy extended AHP-based approach”, Omega, Vol. 35 , pp.417-431.

Che, Z.H., Wang, H.S. and Sha, D.Y. (2007), "A multi-criterion interaction-oriented model with proportional rule for designing supply chain networks", Expert Systems with Applications, Vol. 33, pp.1042-1053. 
Chen, C.T., Lin, C.T. and Huang, S.F. (2006), “A fuzzy approach for supplier evaluation and selection in supply chain management", International Journal of Production Economics, Vol. 102, pp. 289-301.

Chena, C.-T., Lin, C.-T., and Huangb, S.-F. (2006), “A fuzzy approach for supplier evaluation and selection in supply chain management", International Journal of Production Economics, Vol. ,pp.289-301.

Chen, K.L., Chen, K.S. and Li, R.K.(2005), "Suppliers capability and price analysis chart”, International Journal Production Economics, Vol. 98,pp. 315-327.

Erdem, A. S. and Göçen, E. (2012), "Development of a decision support system for supplier evaluation and order allocation”, Expert Systems with Applications, Vol. 39,pp. 4927-4937.

Faez, F., Ghodsypour, S.H. and O’Brien, C. (2007), "Vendor selection and order allocation using an integrated fuzzy case-based reasoning and mathematical programming model", International Journal of Production Economics, doi:10.1016/j.ijpe.2006.11.022.

Guo, M., Zhu, J. and Zhao, X., “A Bi-level Programming Model for Supplier Selection in Constructing Logistics Service Supply Chain”, In: Proc. 2007 IEEE IEEM, 2007, ISBN: $1-4244-1529-2 / 07$.

Gencer, C. and Gürpinar, D. (2007), “Analytic network process in supplier selection: A case study in an electronic firm", Applied Mathematical Modelling, Vol. 31, pp. 24752486 .

Guan, Z., Jin, Z. and Zou, B. (2007), "A Multi-Objective Mixed-Integer Stochastic Programming Model for the Vendor Selection Problem under Multi-Product Purchases", Information and Management Sciences, Vol.18, No. 3, pp. 241-252.

Ghodsypour,S.H. and O’Brien,C.(2001), "The total cost of logistics in supplier selection, under conditions of multiple sourcing, multiple criteria and capacity constraint", International Journal of Production Economics, Vol.73,pp. 15-27.

Ghodsypour,S.H. and O’Brien,C.(1998), “A decision support system for supplier selection using an integrated analytic hierarchy process and linear programming", International Journal of Production Economics, Vol.56-57,pp.199-212.

Hsu, C.-W. and Hu, A. H.(2009), "Applying hazardous substance management to supplier selection using analytic network process", Journal of Cleaner Production, Vol.17,pp.255-264.

Ha, S. H. and Krishnan, R. (2008), "A hybrid approach to supplier selection for the maintenance of a competitive supply chain", Expert Systems with Applications, Vol. 34,pp. 1303-1311. 
Hong, G. and Ha, S. H.(2008), "Evaluating supply partner's capability for seasonal products using machine learning techniques", Computers \& Industrial Engineering, Vol. 54, pp.721-736.

Huang, S. H. and Keskar, H. (2007), "Comprehensive and configurable metrics for supplier selection", International Journal of. Production Economics, Vol. 105 .pp. 510 523.

Hong, G. H., Park, S. C., Jang, D. S. and Rho, H. M. (2005), “An effective supplier selection method for constructing a competitive supply-relationship", Expert Systems with Applications, Vol. 28, pp.629-639.

Handfield, R., Walton, S. V., Sroufe, R., and Melnyk, S. A. (2002), "Applying environmental criteria to supplier assessment: A study in the application of the Analytical Hierarchy Process", European Journal of Operational Research,Vol.141,pp.70-87.

Jharkharia, S. and Shankar, R. (2007), "Selection of logistics service provider: An analytic network process", Omega, Vol.35,pp. 274-289.

Hahn ,C K ,Kim, K H , and Kim ,J S (1986), "Costs of competition: Implications for purchasing strategy", Journal of Purchase and Materials Management (Fall).

Kim, D.Y. and Wagner, S.M. (2011), "Supplier selection problem revisited from the perspective of product configuration”, International Journal of Production Research, pp.1-13.

Kokangul, A. and Susuz, Z.(2008), "Integrated analytical hierarch process and mathematical programming to supplier selection problem with quantity discount", Applied Mathematical Modelling, doi:10.1016/j.apm.2008.01.021.

Kubat, C. and Yuce, B., "Supplier Selection with Genetic Algorithm and Fuzzy AHP", In: Proc. 5th International Symposium on Intelligent Manufacturing Systems, May 2931,2006

Kumar,M., Vrat, P., and Shankar,R.(2004), “A fuzzy goal programming approach for vendor selection problem in a supply chain", Computers and Industrial Engineering,Vol.46,pp.69-85.

Kelle, P and Silver, E A (1990), "Decreasing expected shortages through order splitting”, Engineering Costs and Production Economics, Vol.19,pp.351-357.

Levary, R. R. (2008), "Using the analytic hierarchy process to rank foreign suppliers based on supply risks", Computers \& Industrial Engineering, Vol. 55, pp. 535-542.

Lee, A.H.I. (2009), “A fuzzy supplier selection model with the consideration of benefits, opportunities, costs and risks”, Expert Systems with Applications,Vol.36,pp.2879-2893. 
Lee, A. H.I., Kang, H.-Y. and Chang, C.-T.(2008), "Fuzzy multiple goal programming applied to TFT-LCD supplier selection by downstream manufacturers", Expert Systems with Applications, doi:10.1016/j.eswa.2008.08.044.

Lin, H.-T. and Chang, W.-L.(2008), "Order selection and pricing methods using flexible quantity and fuzzy approach for buyer evaluation", European Journal of Operational Research, Vol.187, pp. 415-428.

Lin, R.-H. (2008), "An integrated FANP-MOLP for supplier evaluation and order allocation”, Applied Mathematical Modelling, doi:10.1016/j.apm.2008.08.021.

Li, G.D., Yamaguchi, D. and Nagai, M. (2007), “A grey-based decision-making approach to the supplier selection problem”, Mathematical and Computer Modelling, Vol. 46, pp. 573-581.

Lee, E., Ha, S. and Kim, S.(2001), "Supplier Selection and Management System Considering Relationships in Supply Chain Management", IEEE transactions on engineering management, vol. 48, No. 3, pp. 307-317.

Mukherjee, K., Sarkar, B. and Bhattacharyya,A. (2013), "Supplier selection by Fcompromise method: a case study of cement industry of NE India", International Journal of Computational Systems Engineering, Vol.1, No.3, pp.162-174.

Mukherjee, S. and Kar, S. (2012), “A three phase supplier selection method based on fuzzy preference degree", Journal of King Saud University - Computer and Information Sciences, http://dx.doi.org/10.1016/j.jksuci.2012.11.001.

Moghadam, M. R. S., Afsar, A. and Sohrabi, B.(2008), "Inventory lot-sizing with supplier selection using hybrid intelligent algorithm", Applied Soft Computing, Vol. 8,pp.1523-1529.

Mehdizadeh, E. and Moghaddam, R. T., "A Hybrid Fuzzy Clustering PSO Algorithm for a Clustering Supplier Problem”, In. Proc. 2007 IEEE IEEM, 2007, ISBN: 1-4244-1529$2 / 07$.

Mouli, K. V. V. C, Subbaiah, K. V., Rao, K. M. and Acharyulu, S. G.(2006), "Particle Swarm Optimization Approach for Vendors Selection”, IE(I) Journal-PR, Vol. 87,pp.3-6.

Moynihan, G.P., Saxena, P. and Fonseca, D. J. (2006), "Development of decision support system for procurement operations", International Journal of Logistics Systems and Management, Vol. 2, No. 1,pp 1-18.

Ng, W. L. (2008), “An efficient and simple model for multiple criteria supplier selection problem”, European Journal of Operational Research, Vol. 186, pp. 1059-1067.

Önüt, S., Kara, S. S. and Işik, E. (2008), "Long term supplier selection using a combined fuzzy MCDM approach: A case study for a telecommunication company", Expert Systems with Applications, doi:10.1016/j.eswa.2008.02.045. 
Parthiban, P., Zubar, H.A. and Garge, C.P.(2012), “A Multi Criteria Making Approach for Suppliers Selection”, Procedia Engineering, Vol.38,pp.2312-2328.

Riedla, D. F., Kaufmann, L., Zimmermann, C. and Perols, J. L.(2012), "Reducing uncertainty in supplier selection decisions: Antecedents and outcomes of procedural rationality", Journal of Operations Management, http://dx.doi.org/10.1016/j.jom.2012.10.003.

Ramasesh , R V ,Ord ,J K , Hayya , J C , and Pan ,A C (1991), "Sole versus dual sourcing in stochastic lead time(s,Q) inventory models", Management Science, Vol. 37, No.4,pp. 428-443.

Shaw, K., Shankar, R., Yadav, S. S. and Thakur, L. S.(2012), "Supplier selection using fuzzy AHP and fuzzy multi-objective linear programming for developing low carbon supply chain”, Expert Systems with Applications, Vol. 39,pp. 8182-8192.

Sawik, T.(2011), "Supplier selection in make-to-order environment with risks", Mathematical and Computer Modelling, Vol. 53,pp.1670-1679.

Soner Kara, S. (2011), "Supplier selection with an integrated methodology in unknown environment”, Expert Systems with Applications, Vol. 38 ,pp.2133-2139.

Sawik, T. (2010), "Single vs. multiple objective supplier selection in a make to order environment", Omega, Vol. 38,pp.203-212.

Saen, R. F. (2007), "Suppliers selection in the presence of both cardinal and ordinal data”, European Journal of Operational Research, Vol. 183, pp. 741-747.

Sarfaraz, A. R. and Balu, R. (2006), “An Integrated Approach for Supplier Selection”, IEEE, ISBN: 0-7803-9701-0/06.

Shyur, H.J. and Shih, H.S. (2006), "A hybrid MCDM model for strategic vendor selection", Mathematical and Computer Modelling, Vol. 44, pp. 749-761.

Tate, W. L., Ellram, L.M. and Dooley, K.J. (2012), "Environmental purchasing and supplier management (EPSM): Theory and practice”, Journal of Purchasing \& Supply Management, Vol.18, pp.173-188.

Ustun, O. and Demirtas, E. A. (2008), “An integrated multi-objective decision-making process for multi-period lot-sizing with supplier selection", Omega, Vol. 36, pp.509 521.

Ustun, O. and Demirtas, E. A.(2007), "Analytic network process and multi-period goal programming integration in purchasing decisions", Computers \& Industrial Engineering, doi:10.1016/j.cie.2006.12.006.

Van der Rhee, B., Verma, R. and Plaschka, G.(2008), "Understanding trade-offs in the supplier selection process: The role of flexibility, delivery, and value-added 
Supplier selection criteria and methods: past, present and future

services/support", International Journal of Production Economics, doi:10.1016/j.ijpe.2008.07.024.

Wang, J. (2012), “Do firms' relationships with principal customers/suppliers affect shareholders' income?”, Journal of Corporate Finance, Vol. 18,pp.860-878.

Wang, W.-P. (2010), "A fuzzy linguistic computing approach to supplier evaluation", Applied Mathematical Modelling, Vol. 34, pp.3130-3141.

Wu, D. D., Zhang, Y., Wu, D. and Olson, D. L.(2010), "Fuzzy multi-objective programming for supplier selection and risk modeling:A possibility approach", European Journal of Operational Research, Vol. 200,pp. 774-787.

Wang, S.-Y., Chang, S.-L. and Wang, R.-C.(2009), “Assessment of supplier performance based on product-development strategy by applying multi-granularity linguistic term sets", Omega, Vol. 37, pp.215 - 226.

Wu, W.-Y., Sukoco, B. M., Li, C.-Y. and Chen, S. H.(2009), "An integrated multiobjective decision-making process for supplier selection with bundling problem", Expert Systems with Applications, Vol. 36, pp. 2327-2337.

Wang, J.-W., Cheng, C.-H. and Cheng, H. K. (2008),"Fuzzy hierarchical TOPSIS for supplier selection”, Applied Soft Computing, doi:10.1016/j.asoc.2008.04.014.

Wu, D. and Olson, D. L.(2008), "Supply chain risk, simulation, and vendor selection", International Journal of Production Economics, Vol. 114, pp. 646-655.

Wu, W. Y., Shih, H.-A. and Chan, H.-C.(2008), "The analytic network process for partner selection criteria in strategic alliances", Expert Systems with Applications, doi:10.1016/j.eswa.2008.06.049.

Wu, M. (2007), "Topsis-AHP simulation model and its application to supply chain management", World Journal of Modelling and Simulation,Vol. 3, No. 3, pp. 196-201.

Yang, J. L., Chiu, H. N., Tzeng, G.-H. and Yeh, R. H.(2008), "Vendor selection by integrated fuzzy MCDM techniques with independent and interdependent relationships", Information Sciences, Vol.178,pp.4166-4183.

Yu, J.-R. and Tsai, C.-C.(2008), “A decision framework for supplier rating and purchase allocation: A case in the semiconductor industry", Computers \& Industrial Engineering, Vol. 55,pp. 634-646.

Xia, W. and Wu, Z. (2007), "Supplier selection with multiple criteria in volume discount environments”, Omega, Vol. 35,pp. $494-504$.

Yao, F. and Hongli, L., "Information Systems Outsourcing Vendor Selection Based on Analytic Hierarchy Process", IEEE,2007,ISBN: 1-4244-1312-5/07. 
Supplier selection criteria and methods: past, present and future

Zhang, D., Zhang, J., Lai, K.-K. and Lu, Y.(2008), "An novel approach to supplier selection based on vague sets group decision", Expert Systems with Applications, doi:10.1016/j.eswa.2008.07.053. 